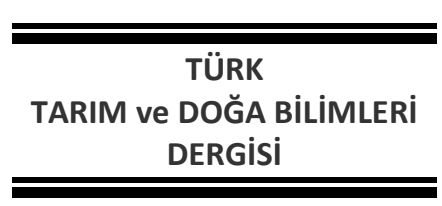

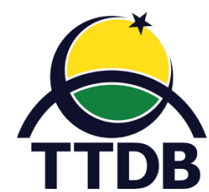

www.dergipark.gov.tr/turkjans

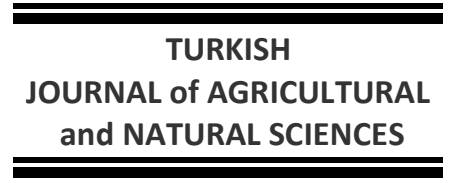

Research Article

Rangeland Health, Condition and Biodiversity in Kırşehir Province

\author{
Ziya MUTLU ${ }^{1 *}$, Sabahaddin ÜNAL ${ }^{2}$, Ali MERMER ${ }^{3}$, Öztekin URLA ${ }^{4}$, Bilal ŞAHIN ${ }^{5}$, Serdar ASLAN ${ }^{6}$ \\ ${ }^{1}$ Ankara University Graduate School of Natural and Applıed Science \\ ${ }^{2}$ Bolu Izzet Baysal University Faculty of Agriculture and Naturel Sciences \\ ${ }^{3}$ Retired Agriculture Engineer \\ ${ }^{4}$ Field Crops Central Research Institute \\ ${ }^{5}$ Çankırı Karatekin University Yapraklı Technical and Business Collage \\ ${ }^{6}$ Düzce University Faculty of Forestry
}

*Corresponding author: aziyamutlu@gmail.com

Received: 08.05.2019

Received in Revised: 02.08.2019

Accepted: 23.08.2019

\begin{abstract}
Rangeland improvement and management have recently become more important that many new projects have been also initiated and conducted throughout Turkey. There is a great responsible for the provinces in the Central Anatolia Region on those implementation projects. In this framework, this study was designed that could contain vegetation surveys in representative sites for rangelands of Kırşehir province in 2008 year, at the same time their assessment, and conclusion were also performed too. The 36 rangeland sites were surveyed with the modified-loop method. The results of vegetation surveys were analyzed and determined rangeland condition and health classes for each sites. The vegetation cover was measured as $65.35 \%$. The rates of decreasers and increasers cover were $11.54 \%$ and $35.26 \%$, respectively. The studied sites numbers were one, 30 and 5 for good, fair, and poor conditions, respectively. The 35 sites of total sites were identified as fair and poor in condition based on the rangeland condition classes. On the other hand, 8 sites were found at healthy, 20 sites at risky and 8 sites at unhealthy in rangeland health categories. Total site numbers of the last two classes were 28. Rangeland biodiversity were calculated as 0.229 by Simpson's index. Survey results showed that rangelands have been overgrazed and seemed degradation. Firstly this trend should be stopped and secondly urgent measures should be implemented for restoration.
\end{abstract}

Key words: Rangeland, rangeland condition, rangeland health.

\title{
Kırşehir îlinde Mera Sağlığı, Durumu ve Biyoçeşitlilik
}

\section{Özet}

Son yıllarda mera ıslah ve yönetimi çalışmaları oldukça önem kazanmış olup ülkemizde bu alanda birçok yeni proje yürütülmektedir. Bölgemizde yer alan iller bu konuda çok sayıda projeye öncülük etmektedir. Bu çalışma Kırşehir ilinde 2008 yılında yapılan mera vejetasyon sörveylerini içermektedir. Çalışmada toplam 36 mera durağına gidilmiş ve modifiye edilmiş tekerlekli lup yöntemine göre mera vejetasyonu ölçülmüştür. Yapılan vejetasyon etüdlerine dayanarak mera durum ve sağlık sınıfları belirlenmiştir. Bitki ile kaplı alan oranı \%65.35 olarak hesaplanmış, azalıcı ve çoğalıcı türlerin oranı sırasıyla \%11.54 ve \%35.26 olarak bulunmuştur. Çalışılan duraklardan 1 tanesi iyi, 30 tanesi orta ve 5 tanesi zayıf mera durum sınıfında yer almıştır. Mera durum sınıfları temel alındığında toplam durakların 35 âdeti orta ve zayıf sınıfa girmiştir. Öte yandan mera sağlık sınıfına baktığımızda; duraklardan 8 tanesi sağlıklı, 20 tanesi riskli ve 8 tanesi sağlıksız sınıfa girmiştir. Toplam durakların 28 âdeti son iki sınıfta yer almıştır. Mera vejetasyonunun biyolojik çeşitliliğini değerlendirmek için hesaplanan Simpson indeks değeri 0,229 olarak belirlenmiştir. Çalışma sonuçları meraların aşırı otlatıldığını ve mera vejetasyonunda bozulma olduğunu göstermiştir. illk olarak il meralarındaki bu aşırı otlatma ve bozulma durdurulmalı, daha sonra meraların rehabilitasyonu için acil önlemler devreye sokulmalıdır. 
Anahtar kelimeler: Mera, mera durum sınıfı, mera sağlık sınıfı.

\section{Introduction}

Rangeland is a complex subject closely related to many other issues such as animal, ecology, biodiversity, climate, soil, altitude, topography, etc.. Its environmental point is considered to face in-depth of flora, fauna, wild animals, domestic animals, climatic change and global warming. Its protection, improvement, and management are important tools for use in current and future sustainable rangeland. Improper management commonly used (early, heavy and late grazing) causes loss of biodiversity and increasing erosion impact (Mermer et al, 2010). Rangelands have been declined from 40 million hectares to 14.6 million hectares. During this period, their carrying capacities have also reduced. The results of mismanagement emerge as reducing yield and biodiversity loss on rangelands. Farmers are reluctant to improve common rangelands with no ownership and no charge for their use. Common using of rangelands in Kırıkkale and Sivas provinces in the Central Anatolia Region are grazed more 1.87.0 livestock unit than carrying capacity (Anonymous, 2009). There are existing large rangeland areas (percentage, 30.0\%) of Turkey in the Central Anatolia Region. In the past, rangeland studies were conducted and completed. But during the between period of 2007 and 2011, intensive rangeland vegetation studies were carried out (Anonymous, 2012). At the beginning of rangeland studies, descriptions and properties of rangeland are identified such as area, botanical composition, climatic data, aspect, slope, etc.. Plant species of rangeland community were observed in this study. They were identified for condition, health and biodiversity aspects.

\section{Material and Methods}

The study site, Kırşehir, is located in the Central Anatolia Region, bounded by latitudes $37.97^{\circ}-39.65^{\circ} \mathrm{N}$ to and longitudes $33.18^{\circ}-34.45^{\circ} \mathrm{E}$. The elevation of the working area range from $860 \mathrm{~m}$ to $1310 \mathrm{~m}$. The region has typical continental climatic characteristics, and receives most of the yearly precipitation in winter, autumn and spring (average $378 \mathrm{~mm}$ ). Summer is hot and dry and winter is cold. The average temperature is $11.3^{\circ} \mathrm{C}$; it ranges from below $\theta \circ \mathrm{C}$ in December and January to $39{ }^{\circ} \mathrm{C}$ in July and August (Anonymous, 2008a).

The texture of soil of the study area differs from clay-loam to loam, and depth is broadly very shallow. The soil is slightly alkaline, lime content varies from low to very high amount of lime, very low phosphorus, rich potassium content, low and fair organic matter content (Anonymous, 2008b). A modified wheel point method with loop for the vegetation survey was applied (Koç and Çakal, 2004) at the representative 36 sites of Kırşehir province in 2008 (Figure 1). Two transect lines, each of $100 \mathrm{~m}$ in length and perpendicular to each other, were studied at each site. A total of 400 readings with $0.50 \mathrm{~m}$ intervals was recorded on two transects to determine cover percentages of plant species and bare ground area on rangeland vegetation. The rangeland condition, based on proportion of decreasers and increasers, were classified as excellent, good, fair and poor. Health categories of rangeland were determined as healthy, at risky, and unhealthy by considering soil coverage proportion of vegetation (Koç et al. 2003). In addition habitat characteristics of altitude, aspect, slope, and distance to village and rangeland management practices such as grazing intensity, erosion, and soil compactness were recorded during vegetation survey. Rangeland area is about 129027 ha and covers $19.2 \%$ of the province (PAED 2008). The total livestock number of the province is 73337 large animal units (LAUs) in 2008 (TUIK 2008). It is estimated that annual hay need was 334600 tons. The hay production amount is calculated for rangelands as 25805 tons which accounts for $7.7 \%$ of total need.

\section{Biodiversity index}

Vegetation diversity of rangeland vegetation is evaluated by calculating Simpson's index (D) (Simpson, 1949). This index uses both species richness and an evenness of abundance among the species present. The formula for calculating Simpson's index is:

$$
\mathrm{D}=\frac{\sum \mathrm{n}_{i}\left(\mathrm{n}_{i}-1\right)}{\mathrm{N}(\mathrm{N}-1)}
$$

Where, $\mathrm{n}_{i}=$ the number of individuals of each individual species $\mathrm{N}=$ the total number of organisms of all species.

The value of $D$ ranges from 0 to 1 . With this index, 0 represents infinite diversity and, 1 , no diversity. That is, the bigger the value the lower the diversity. To calculate the index, frequencies of all species record on each sampling point was adjusted so that the total frequency would be made up to 100. 


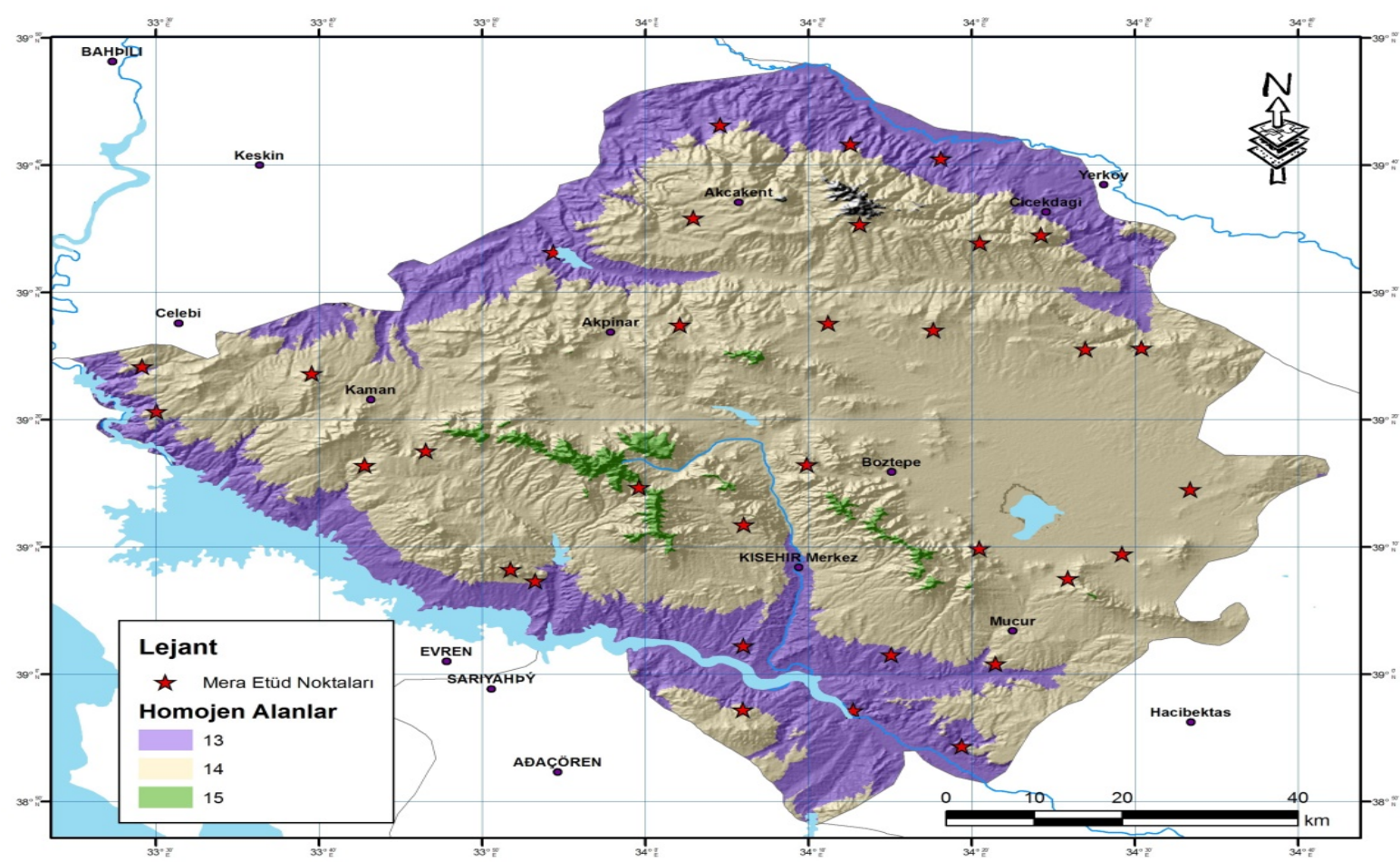

Figure 1. Study sites in map of Kırşehir.

\section{Results and Discussions}

The rangeland condition in Kırşehir province was calculated and grouped as "fair" class (the total values of decreasers and increasers as 31.82\%) based on plant species cover (Table 1). Moreover, the proportions of decreaser, increaser and invader species in botanical composition calculated as $11.54 \%, 35.26 \%$, and $53.51 \%$, respectively. Health class of Kırşehir rangelands was in a "risky" category since the percentages of vegetation cover and bare ground calculated as $65.35 \%$ and $34.65 \%$, respectively (Table. 1). Ankara, Çankırı, Kayseri, Sivas and Mardin provinces became similar status for range condition and health, in a fair and at risky, respectively (Ünal et al. 2012a; Ünal et al. 2012b; Ünal et al. 2013; Ünal et al. 2014; Seydoşoğlu et al. 2018). Overgrazing, a major problem for especially this region, may be reason for the undesirable rangeland status.

Table 1. Botanical composition, bare ground and rangeland health values

\begin{tabular}{ccccccccc}
\hline DS & BC & BG & DBC & IBC & IBC $_{1}$ & IURC & SURC \\
\hline Minimum & 35.50 & 4.75 & 0.26 & 2.97 & 21.74 & 2.97 & 7.39 \\
Maximum & 95.25 & 64.50 & 40.00 & 74.55 & 92.61 & 35.00 & 52.20 \\
Average & $\mathbf{6 5 . 3 5}$ & $\mathbf{3 4 . 6 5}$ & $\mathbf{1 1 . 5 4}$ & $\mathbf{3 5 . 2 6}$ & $\mathbf{5 3 . 5 1}$ & $\mathbf{2 0 . 6 0}$ & $\mathbf{3 1 . 8 2}$ \\
Standard error & 12.70 & 12.70 & 8.91 & 16.08 & 14.81 & 5.95 & 8.61 \\
CV(\%) & 19.43 & 36.66 & 77.20 & 45.61 & 27.67 & 28.91 & 27.07 \\
\hline
\end{tabular}

*BC: Botanical composition (\%) BG: Bare ground (\%) DBC: Decreasers on Botanical composition (\%) IBC: Increasers on Botanical composition (\%) $\mathrm{IBC}_{1}$ : Invaders on Botanical composition (\%) IURC: Increasers Used for Range Condition SURC: Species Used for Range Condition (\%) CV: Coefficient Variation DS: Descriptive statistics.

\section{Rangelands condition and health Rangeland health}

Rangeland health values were presented in Table 2. The percentages of vegetation cover and bare ground were calculated as $81.63 \%$ and $18.38 \%$; $65.90 \%$ and $34.10 \% ; 47.72 \%$ and $52.28 \%$ at healthy ( 8 sites), risky (20 sites), and unhealthy (8 sites) respectively (Table 2 ). Out of 36 rangeland sites, 28 sites were found "risky" and "unhealthy" health classes. The percentages of vegetation cover and bare ground at healthy, risky, and unhealthy of the health classes were obtained to be as $77.75 \%$ and $22.25 \% ; 63.77 \%$ and $36.23 \% ; 49.30 \%$ and $50.70 \%$ in Ankara (Unal et al. 2012a), $79.04 \%$ and $20.96 \%$; 64.52\% and $35.48 \% ; 46.23 \%$ and $53.77 \%$ in Cankiri (Unal et al. 2012b), $83.42 \%$ and $16.58 \% ; 62.33 \%$ and $37.67 \%$; $48.21 \%$ and $51.79 \%$ in Kayseri (Ünal et al. 2013), 80.90\% and $19.10 \% ; 62.15 \%$ and $37.85 \%$; $46.94 \%$ and $53.06 \%$ in Sivas (Ünal et al. 2014), respectively. 
The highest vegetation cover was $95.25 \%$ in healthy rangeland class. The lowest and the highest values on botanical composition in the same following continuously classes for these three health classes were measured as $76.00 \%, 95.25 \%$; $56.75 \%, 73.25 \%$ and $35.50 \%, 53.75 \%$, respectively. According to the coefficient variations of botanical composition in the same Table, healthy $(7.42 \%)$ and risky $(7.77 \%)$ but unhealthy $(13.25 \%)$ of rangelands had a higher value than theirs. The mentioned data above indicated that region provinces rangelands have continued degradation trend. Overgrazing and mismanagement have immediately stopped and started rehabilitation projects.

Table 2. Botanical composition, bare ground and rangeland health values

\begin{tabular}{|c|c|c|c|c|}
\hline Health classes & Site numbers & DS & $\mathrm{BC}(\%)$ & BG (\%) \\
\hline \multirow{5}{*}{ Healthy } & \multirow{5}{*}{8} & Minimum & 76.00 & 4.75 \\
\hline & & Maximum & 95.25 & 24.00 \\
\hline & & Average & 81.63 & 18.38 \\
\hline & & Standard error & 6.05 & 6.05 \\
\hline & & CV (\%) & 7.42 & 32.95 \\
\hline \multirow{5}{*}{ Risky } & \multirow{5}{*}{20} & Minimum & 56.75 & 26.75 \\
\hline & & Maximum & 73.25 & 43.25 \\
\hline & & Average & 65.90 & 34.10 \\
\hline & & Standard error & 5.12 & 5.12 \\
\hline & & CV (\%) & 7.77 & 15.01 \\
\hline \multirow{5}{*}{ Unhealthy } & \multirow{5}{*}{8} & Minimum & 35.50 & 46.25 \\
\hline & & Maximum & 53.75 & 64.50 \\
\hline & & Average & 47.72 & 52.28 \\
\hline & & Standard error & 6.32 & 6.32 \\
\hline & & CV (\%) & 13.25 & 12.09 \\
\hline
\end{tabular}

\section{Rangeland condition}

The conditions data is presented in Table 3. In the province of Kırşehir, 1 site was identified as good, 30 sites were as fair, and 5 sites were calculated as poor of the three different classes of rangeland conditions. Fair and poor sites numbers were 35 (Table 3 ). The only 1 site of the 36 sites were in a good rangeland condition and its decreasers cover, the highest percentage figure, was found as $40.00 \%$ in the botanical composition. The highest percentages of increaser and invader species in botanical composition of fair and poor conditions were $74.55 \%$ and $92.61 \%$, respectively. These values are early an indicator for fast rangeland degradation. If there won't be precautions taken for improvement and reverse of present status, it may be too late in the near future. The decreasers and increasers cover in good rangeland conditions were measured as $43.09 \%$ and $32.87 \%$ in Ankara (Unal et al. 2012a), $49.36 \%$ and $13.33 \%$ in Cankiri (Unal et al. 2012b), $70.25 \%$ and $0.00 \%$ in Kayseri (Ünal et al. 2013), 34.96\% and $33.35 \%$ in Sivas (Ünal et al. 2014), respectively. The highest cover rate of decreasers was in Kayseri in this categorize. Out of 36 survey sites, 30 rangeland sites were found in "fair" class, and their percentages of decreasers and increasers in botanical composition were $11.26 \%$ and $38.31 \%$, respectively (Table 3 ). As seen invader species spread in a wider area on vegetation community cover due to misused or overgrazing palatable species. Invader species cover expanded and reached to high rate as $92.61 \%$.

The decreasers and increasers covers of fair rangeland conditions were measured as $15.13 \%$ and 28.91\% in Ankara (Unal et al. 2012a), 15.19\% and 25.33\% in Cankiri (Unal et al. 2012b), 15.82\% and $27.08 \%$ in Kayseri (Ünal et al. 2013), 17.92\% and $25.83 \%$ in Sivas (Ünal et al. 2014), 1.17\% and 9.50\% in Batman (Seydoşoğlu et al. 2019) respectively. The coefficient variation values of decreaser and increaser species were $64.97 \%$ and $39.73 \%$ in the fair condition respectively (Table 3 ). It seems to be more pressure on decreaser species. Rangeland vegetation in Kırşehir province had the lowest rate of decreasers and the highest rate of increasers in the fourth provinces mentioned above.

The portion of decreasers and increasers of botanical composition were $5.26 \%$ and $21.58 \%$ respectively, on 5 sites of "poor" class of rangeland condition (Table 3).

The highest invader's rate $(73.16 \%)$ was found in the "poor" category among the three classes. The effects of mismanagement are clearly seen in this category. The composition of decreasers and increasers covers in poor rangeland conditions were calculated as $4.21 \%$ and $22.66 \%$ in Ankara (Unal et al. 2012a), 3.13\% and $27.13 \%$ in Cankiri (Unal et al. 2012b), $7.16 \%$ and $12.88 \%$ in Kayseri (Ünal et al. 2013), 7.81\% and 13.93\% in Sivas (Ünal et al. 2014), respectively. Rangeland vegetation in Kırşehir province had a similar rate for 
decreasers and the increasers to the fourth provinces previous presented.

Table 3. Rangeland conditions of sites and the percentages of decreasers, increasers, and invaders on botanical composition

\begin{tabular}{|c|c|c|c|c|c|c|c|}
\hline Rangeland condition & Site numbers & DS & DBC & IBC & $\mathrm{IBC}_{1}$ & IURC & SURC \\
\hline Good & 1 & $\begin{array}{l}\text { Minimum } \\
\text { Maximum } \\
\text { Average } \\
\text { Standard error } \\
\text { CV (\%) } \\
\end{array}$ & 40.00 & 12.20 & 47.80 & 12.20 & 52.20 \\
\hline \multirow{5}{*}{ Fair } & \multirow{5}{*}{30} & Minimum & 0.26 & 2.97 & 21.74 & 2.97 & 20.58 \\
\hline & & Maximum & 28.62 & 74.55 & 69.90 & 35.00 & 50.40 \\
\hline & & Average & 11.26 & 38.31 & 50.43 & 21.74 & 33.00 \\
\hline & & Standard error & 7.57 & 15.22 & 12.93 & 5.37 & 6.68 \\
\hline & & CV(\%) & 64.97 & 39.73 & 25.64 & 24.68 & 20.25 \\
\hline \multirow{5}{*}{ Poor } & \multirow{5}{*}{5} & Minimum & 0.39 & 7.00 & 63.49 & 7.00 & 7.39 \\
\hline & & Maximum & 13.03 & 33.61 & 92.61 & 20.00 & 25.05 \\
\hline & & Average & 5.26 & 21.58 & 73.16 & 15.42 & 20.68 \\
\hline & & Standard error & 4.74 & 12.12 & 12.01 & 6.37 & 7.49 \\
\hline & & CV (\%) & 90.07 & 56.17 & 16.42 & 41.28 & 36.24 \\
\hline
\end{tabular}

\section{Plant species}

The number of plant species is a good measure for vegetation diversity. The number of plant species (204) was lowest in Kırşehir rangelands comparing to the number of species found in rangelands of the other provinces of the region such as Sivas, Çankırı, Kayseri, Ankara and Batman having 422, 327, 263, 287 and 202 plants species, respectively (Ünal et al. 2012a; Ünal et al. 2012b; Ünal et al. 2013; Ünal et al. 2014; Seydoşoğlu and Kökten 2019). The nine and thirteen plant species were decreasers and increasers (the desired palatable species), respectively. The rates of decreasers, increasers, and invaders on botanical composition were presented in Table 1. Palatable species and total plant species numbers are important for improvement and biodiversity of the rangelands. In this study, decreaser grasses are as follows: Bothriochloa ischaemum, Bromus tomentellus, Chrysopogon gryllus, Koeleria cristata, Poa pratensis, Medicago sativa, Medicago varia, Onobrychis armena, and Trifolium pretense.

Decreasers were observed in the former studies are as follows: Agropyron cristatum, Bromus tomentellus, Koeleria cristata (Ünal et al. 2012a; Ünal et al. 2012b; Ünal et al. 2013) Dactylis glomerata, Elymus repens, Lotus aegaeus, $L$. corniculatus, Onobrychis armena, Onobrychis oxyodonta, Trifolium pretense, and Vicia cracca. (Ünal et al. 2012a; Ünal et al. 2012b) Agrostis stolonifera, Elymus hispidus, Phleum montanum and Poa pratensis (Ünal et al. 2013), Onobrychis occulta and $O$. oxyodonta, Hedysarum pestalozzae (Ünal et al. 2013), Andropogon gryllus, (Bakır 1970;
Tokluoğlu 1979; Ünal et al. 2013) and Festuca ovina (Bakır 1970; Özmen 1977; Uluocak 1977; Ünal et al. 2010; Ünal et al. 2011; Ünal et al. 2013) Poa bulbosa, Cynodon dactylon, (Bakır 1970; Ünal et al. 2012a; Ünal et al. 2012b; Ünal et al. 2013), Hedysarum varium (Bakır 1970; Tokluoğlu 1979; Ünal et al. 2013), Medicago sativa (Bakır 1970; Uluocak 1977; Ünal et al. 2013), Onobrychis armena (Bakır 1970; Ünal et al. 2010) and Onobrychis sativa, O. alba, O. tenuifolia (Uluocak 1977). Increaser grasses were found as Coronilla scorpioides, Cynodon dactylon, Ebenus laguroides, Festuca valesiaca, Hordeum bulbosum, Juncus gerardi, Pennisetum orientale, Plantago holosteum, Poa bulbosa, Stipa holosericea, Stipa lessingiana, Teucrium polium and Trigonella brachycarpa. Identified increasers before were such as Stipa holosericea (Ünal et al. 2012a; Ünal et al. 2012b; Ünal et al. 2013). Poa alpine, Hordeum bulbosum and Hedysarum cappadocicum (Ünal et al. 2012a; Ünal et al. 2013), Plantago lanceolata, and Teucrium polium (Ünal et al. 2012a; Ünal et al. 2012b) Dorycnium pentaphyllum, Ebenus hirsuta, (Ünal et al. 2012a) Briza media, Ebenus laguroides, Puccinellia koeieana (Ünal et al. 2013). In the past surveys and this study were encountered similar plant species such as Hedysarum varium (Bakir, 1970; Tokluoglu, 1979), Medicago sativa (Bakir, 1970; Uluocak, 1977), Onobrychis armena (Bakir, 1970; Unal et al., 2010) and Onobrychis sativa, O. alba, O. tenuifolia (Uluocak, 1977) that are all considered potentially to be most important to be rehabilitated and over-seeded for region vegetation community. These incresears as Cynodon dactylon, 
Plantago lanceolata, P. bulbosa, Stipa holosericea, and Teucrium polium also occurred in Ankara and Cankiri provinces (Unal et al., 2012a; Unal et al., 2012b). Poa bulbosa var.vivipara, and Cynodon dactylon were also found in the previous survey (Bakir, 1970). Unal et al., (2012a) studied in vegetation of Ankara province and reported other increaser species such as Hordeum bulbosum, Poa alpine, Dorycnium pentaphyllum, Ebenus hirsuta, Hedysarum cappadocicum.

Some invader species in Kırşehir were Alyssum desertorum, A. pateri, Artemisia santonicum, Taeniatherum caput-medusae, Eryngium campestre, Euphorbia macroclada, Phlomis pungens, Potentilla recta, Salvia cryptantha, Teucrium chamaedrys, Thymus sipyleus, Ziziphora capitata. Dominant plant species on regional rangelands are as follows: Thymus squarrosus (Thymus sipyleus) (Bakır 1970; Özmen 1977; Tokluoğlu 1979; Ünal et al. 2010; Ünal et al. 2011; Ünal et al. 2013), Artemisia fragrans (Artemisia santonicum) (Özmen 1977; Tokluoğlu
1979; Ünal et al. 2010; Ünal et al. 2011; Ünal et al. 2013).

\section{Biodiversity of rangelands}

To evaluate biodiversity of sampling sites of Kırşehir province, Simpson's index values were determined (Table 4). Species diversity found high in site 4 vegetation of Kırşehir province based on index value (0.507). Low index value became 0.107 in site 29. Average Simpson index was 0.229. Grazing pressure is high on the Central Anatolia rangelands that's why number of species reduced and limited number of species such as Festuca ovina or several annual species became dominant in grassland vegetation. Low species diversity indicates stressful environment. Dry and semi-arid conditions causes low species diversity (De Bello et al., 2006). According to Canals and Sebastian (2000), for the development of management practices that prevent ecological degradation, it is necessary to know mechanism for preserving biodiversity in different ecosystems.

Table 4. Simpson's index values for Kırşehir province.

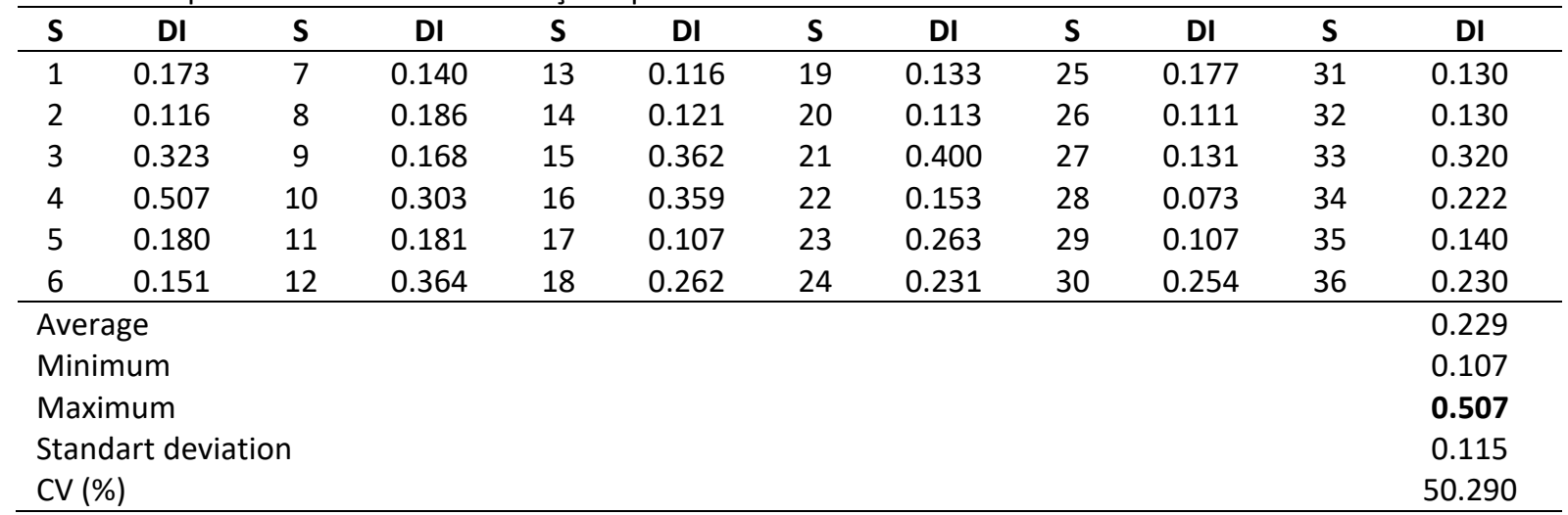

*DI: Simpson's index values, S: Sites.

\section{Conclusions}

While range condition was identified as fair, health classes were identified as risky. 8 sites of Kırşehir Province's rangelands were in a healthy class, 20 sites were at risky class and 8 sites were at unhealthy class. 1 site of the rangelands of Kırşehir 11 Province was in a good condition, 30 sites were in fair condition, and 5 sites were in poor condition. In the history of rangeland management, the status of 35 sites in total -fair and poor-is an indication of misuse. Palatable plant species existed on vegetation community, thus they may be important for over-seeding of degraded rangeland areas.

Rangelands have still used with early, late, and overgrazing for long term. Firstly this trend should be stopped, secondly it should be reversed in a restoration way. For healthy and good condition classes, present situation should be kept on with sound management techniques as fertilization and proper grazing system. For risky, unhealthy, fair and poor condition class, all improvement activities should be well planned as weed control, fertilization and proper grazing system. In addition, forage crops should be pay attention to support all improvement activities to produce for animal needs. Monitoring on vegetation changes should be also followed in a certain time period.

\section{Acknowledgments}

This field vegetation survey was fulfilled in the framework of National Rangeland Management and Use Project. It was supported by The Scientific and Technological Research Council of Turkey (TUBITAK- (KAMAG Project No: 106G017), General Directories of Plant Production and Food and Control of Republic of Turkey Ministry of Food, Agriculture and Livestock. 


\section{References}

Anonymous, 2008a. The Climatic Data of Kırşehir Province. The General Director of State Meteorological Service, Ankara, Turkey.

Anonymous, 2008b. Soil Analysis Results of Studied Sites of Kırşehir Province. Central Soil, Fertilizer and Water Resources Research Institute, Ankara.

Anonymous, 2009. The Challenge of the Rangelands in Turkey (Towards a Sustainable Rangeland Economy). Government to government project G2G07/TR/9/3 Turkey The Netherlands, Final report of the G2G project: sustainable rangeland management in Turkey, 2008 and 2009, 57 p.

Anonymous, 2012. The Result Report of National Rangeland Use and Management Project, project no: 106G017. The Scientific and Technological Research Council of Turkey (TÜBITAK) Support Programme for Research and Improvement Projects of Public Institutions (1007 Programme), Public Research Grant Committee, (Unpublished Report).

Bakir, O., 1970. A Rangeland Vegetation Survey in the Field of Middle-East Technical University. Ankara University, Agricultural Faculty Presses, 382 p., Ankara.

De Bello, F., Lepš, J., Sebastia', M.T. 2006. Variations in species and functional plant diversity along climatic and grazing gradients. Ecography, 29: 801-810.

Canals, R.M., Sebastia, M.T. 2000. Analyzing mechanisms regulating diversity in rangelands through comparative studies: $A$ case in the South-Western Pyrennes. Biodiversity and Conservation, 9: 964-984.1

Koc, A., Gokkus, A., Altin, M. 2003. Comparison of commonly used determination methods of rangeland condition in the world and a suggestion for Turkey. Turkey V. Field Crops Congress, 13-17 October, Diyarbakir, pp. 3642.

Koc, A., Cakal, S. 2004. Comparison of some rangeland canopy coverage methods. Int. Soil Cong. On Natural Resource Manage, for Sust. Develop., June 7-10, 2004, Erzurum, Turkey, D7, pp. 41-45.

Mermer, A., Özaydın, K.A., Ünal, S., Avağ, A, Mutlu, Z., Yıldız, H., Aydoğdu, M., Ünal, E., Urla, Ö., Şahin, B., Torunlar, H., Dedeoğlu, F., Tuğaç, M.G., Aydoğmuş, O. 2010. Kırşehir Illinde Mera Vejetasyonunun Değerlendirilmesi. Çölleşme ile mücadele sempozyumu, 16-17 Haziran 2010, Çorum.
Ozmen, T. 1977. The Trials on the Vegetation of the Rangeland in Konya Province. Ph.D thesis (not printed), Rangeland-Meadow and Livestock Research Institute, Ankara.

PAED, 2008. Agricultural Data of Kırşehir Province. The Provincial Agriculture Extension Directorates, Kirşehir, Turkey.

Seydoşoğlu, S., Kökten, K., Sevilmiş, U. 2018. Basic vegetation characteristics of village pastures connected to Mardin province and its provinces. Turkish Journal of Agricultural and Natural Science, 5(4): 406-413.

Seydoşoğlu, S., Çaçan, E., Sevilmiş, U. 2019. Determination of botanical composition, yield and pasture quality ratings of infertile pastures in Kozluk district of Batman province of Turkey. Fresenius Environmental Bulletin, 28(4A)p: 3388-3394.

Seydoşoğlu, S., Kökten, K. 2019. Some characters of rangeland vegetation in Batman province. Harran Journal of Agricultural and Food Science, 23(1): 60-68.

Simpson, E.H. 1949. Measurement of diversity. Nature, 163: $\quad$ (4148): 688 doi:10.1038/163688a0.

Tokluoglu, M. 1979. Studies on Morphological, Biological and Agronomical Important Characters of Some Rangeland Plants. Ankara University, Agricultural Faculty Press no: 728, Ankara.

TUiK, 2008. Agriculture - Crop Production Statistics. Turkish Statistical Institute.

Uluocak, N. 1977. Rangelands and Rangelands in the Forest. The Ministry of Food- Agricultural and Livestock, the General Directorate of the Agricultural Affairs, 6.

Unal S., Dedebali, M., Ocal, M.B., 2010. Ecological Interpretations of rangeland condition of some villages in Kirikkale province of Turkey. Turkish J. of Field Crops, 15(1): 43-49.

Unal, S., Karabudak, E., Ocal, M.B. 2011. Interpretations of vegetation changes of some villages rangelands in Cankiri province of Turkey. Turkish J. of Field Crops, 16(1): 3947.

Unal, S., Mutlu, Z., Mermer, A., Oztekin, U., Unal, E. M. Aydogdu, F. Dedeoglu, K.A. Ozaydin, A., Avag, O. Aydogmus, B. Sahin, and S. Aslan, 2012a. A study on assessment of rangelands in Ankara province. J. of Field Crops Central Research Institute, 2 (21): 41-49.

Unal, S., Mutlu, Z., Mermer, A. Oztekin, U., Unal, E., Ozaydin, K.A., Avag, H., Yildiz, O., Aydogmus, B., Sahin, S., Aslan, S. 2012b. A study on determination of condition and health of rangelands in Cankiri province. Tabad- 
Research J. of Agricultural Sciences, 5(2):131-135.

Ünal, S., Mutlu, Z., Urla, Ö., Yıldız, H., Y., Şahin, B. 2013. Evaluation and determination of rangeland vegetation in Kayseri province. Journal of Field Crops Central Research Institute, 22(2): 86-95.

Ünal, S., Mutlu, Z., Urla, Ö., Yıldız, H., Aydoğdu, M., Şahin, B., Aslan, S. 2014. Improvement possibilities and effects of vegetation subjected to long-term heavy grazing in the steppe rangelands of Sivas. Journal of Field Crops Central Research Institute, 23(1): 2230. 